\title{
Rejoinder to Huemer on Animal Rights ${ }^{1}$
}

\author{
Walter E. Block \\ Loyola University New Orleans \\ 6363 St. Charles Avenue \\ Box 15, Miller Hall 318 \\ New Orleans LA 70118, USA \\ e-mail:wblock@loyno.edu
}

\begin{abstract}
:
Heumer and I debate animal rights, utilitarianism, libertarianism, morality and philosophy. We agree that suffering is a problem, and diverge, widely, on how to deal with it. I maintain that this author's reputation as a libertarian, let alone an intellectual leader of this movement, is problematic. Why? That is because libertarianism, properly understood, is a theory of intra-human rights; this philosophy says nothing about right from an extra-human perspective, Heumer to the contrary notwithstanding. That is to say, he is improperly importing into the freedom philosophy considerations extraneous to it.

Keywords: vegetarianism, libertarianism, animal rights, utilitarianism.
\end{abstract}

\section{Introduction ${ }^{2}$}

This is part IV in a debate between my colleague and friend Michael Heumer and me on the ethical and legal status of vegetarianism and animal rights. Part I was Heumer [32], a book that set out his views on this matter. Part II consisted of my critical review of that book [20]. Part III constituted Heumer's 2021 [33] rejoinder to that book review of mine.

If I were to summarize this disagreement between us, it would be that Heumer supports the doctrine of animal rights, and I do not. But there is much more to this dispute than that, to which we now turn. I follow the organization of [33], since it is very coherent. ${ }^{3}$

In this section of his reply to me, this author offers a curious point: that it is illicit, or improper, or not quite Kosher, for a critic of a book to focus on any statement in this publication which is "beside the point" of its main thesis. Since the essence of his book concerns veganism and animal rights, he declines to defend his writings against my criticisms of the points he makes about legalizing insider trading, the use of the word "them," ending trade with China, and torturing cats if needed for research in order to find a cure for cancer. I find this problematic. An author is responsible for every word he publishes, even en passant, not just those involving his main thesis. Heumer's views on all these points are erroneous in my opinion, and I would have welcomed the opportunity to criticize any defense of 
them he might have made. Why is this important? It is important because at least one of the purposes of scholarly articles, debates, such as which he and I are now having, is to push out the frontiers of knowledge. If we are to be constrained to only discussing issues that are exactly "on point" then, to that extent, we do not adhere to one of the reasons for the existence of this scholarly literature.

\section{Methodological Points}

\subsection{The Argument from Libertarianism}

My debating partner starts off this section with the criticism that I engage in "the Argument from Libertarianism." That is, that I upbraid him for deviating from this philosophy. He deflects this criticism on the ground that he is in effect a free spirit. He looks at philosophical issues on a one by one basis. True, it cannot be denied, most of his views are indeed congruent with the freedom philosophy, but he does not hold them because of this. He maintains them because they seem correct to him, and he is always open to taking positions that are incompatible with that viewpoint.

He states that I criticize him "more than once for not arguing in libertarian-typical ways or taking sufficiently libertarian positions... Despite being a libertarian myself, I find this argument form not at all persuasive. I do not accept any position simply because it is the libertarian position. I first figure out what I believe about a variety of philosophical issues, then look for labels to describe my views. I call myself a libertarian because that term happens to correspond to my political views."

He and I are passing each other on this matter like ships in the night. I would scarcely content myself by demonstrating that the likes of Bernie Sanders, or Paul Krugman or John Rawls were not libertarian, and leave the matter at that. This would be like shooting fish in a barrel. Why, then, am I disparaging this author on that ground?

It is because I am a social scientist. A large part of all science, any science, is categorization [5]. Chemistry consists of more than the periodic table of the elements but that is of the utmost importance in this discipline. Ditto for genus and species in biology. Economics has microeconomics and macroeconomics. Why should political philosophy be any different? It is important in this discipline also, to separate the sheep from the goats. From the perspective of libertarianism, it is of great interest to know who is one, and who is not. In the case of Michael Heumer, he is not only widely considered to be a member of the fold, but, to be an important leader of this entire philosophical movement. ${ }^{4}$ Is it therefore as totally out of bounds as he seems to think it is, to test this hypothesis? I think not. Enquiring minds want to know if he deserves the honorific not only of supporter of the freedom philosophy, but as one of its important contributors.

Heumer misinterprets my comments in Block [20] as

"Positive Argument from Libertarianism:

"Libertarianism says that $\mathrm{P}$.

"Therefore, P."

Au contraire. I am instead subjecting the claim that this author deserves his reputation as one of the most profound contributors to this philosophy to an empirical test. It would appear at the outset, however, that Heumer's libertarian credentials are somewhat suspect. He states:

One must of course hold a consistent set of beliefs. But there is no inconsistency in holding libertarian views about some issues but not others. For instance, there is nothing inconsistent in supporting gun rights, capitalism, and ethical vegetarianism - regardless of whether the last position counts as 'libertarian' or not. If Block is right (I don't think that he is) that libertarianism only recognizes crimes with human victims, then so much the worse for libertarianism... 
Pardon me for saying this, but "so much the worse for libertarianism" does not exactly ring the libertarian bell.

Heumer's next sally against my critical review of his book is as follows:

"The Negative Argument from Libertarianism:

"Libertarianism doesn't say that P.

"Therefore, who cares about P?"

Again, Professor Heumer sees things quite differently. I am trying to measure the congruency of his position with libertarianism. So, of course, anything having nothing to do with this philosophy is not of interest, in this endeavor. But I must acknowledge his sense of humor. I almost died laughing at his depiction of my "cousin" heart surgeon Dr. Joe Block who is totally uninterested in whether his patient is having a heart attack or not. This is really rolling on the floor in a paroxysm of laughter material. But in a serious vein, there is such a thing as specialization and the division of labor. One must sometimes put the "blinders" on, and focus, narrowly, on the issue at hand. To do so in this case, one must ignore irrelevancies, however important they are for other purposes.

I am of course not "completely uninterested in moral questions." I am interested for the purposes of this book review, in but one and only one sub-category of ethics: that pertaining to the libertarian focus on property rights, the initiation of violence, and just punishment for malefactors. This does not at all mean that I do not "care about any other kind of wrong, or any other problem, besides the problem of unjust law." I also care about music, and love and sports and chess; but not for the purpose of evaluating an author's adherence to libertarian principle. If this makes me a "psychopath" as Heumer charges I embrace that mental illness.

Our author continues: “... just a few years of factory farming causes a greater total quantity of suffering than all the human suffering in all of history. Note that Walter Block does not dispute any of these facts. To react to such a problem with indifference would be a shockingly nihilistic stance."

Who says that I react to this fact with "indifference"? Not I, not I, nor does Heumer quote me to that effect. He cannot, since I never wrote anything of the sort. Let us return to my cousin Dr. Joe Block. He is a heart surgeon. When he is working on a patient he focusses narrowly, and fully, on that one organ. He does not give a rat's rear end about the patient's toe, nose, ankle or ear; he totally ignores starvation in poor countries; if there were an asteroid heading toward earth, he would be "indifferent" to such a threat. Can this behavior of this be justified? Of course it can. He wants to do a good job on the heart transplant he is now working on. Well, I want to succeed in determining if Heumer is a libertarian or not, and the best way to do so is to concentrate on that one narrow issue, like my made up "cousin," Joe.

\subsection{Extremism}

Here, again, my favorite Colorado philosophy professor parts company. He avers that I like, have a penchant for, revel in, extremism. It is true that I appreciate Barry Goldwater's famous statement "Extremism in defense of liberty is no vice. Moderation in pursuit of justice is no virtue." But in my book review I was praising Professor Heumer, along with Bernie Sanders, both with whom I disagree, for their courage, not their extremism. I am not at all of the opinion that "thinkers should take up extreme, unqualified generalizations with high confidence" and I cannot understand what might have led Heumer into ascribing this irrational view to me. Certainly, he does not quote me to this effect, since I wrote nothing along those lines. 


\section{Objections to the Case for Ethical Veganism}

\section{1. "Suffering Can Be Good"}

Heumer's "central case for veganism turns on the vast pain and suffering caused by human consumption of animal products." He continues: "But Block argues that pain and suffering can sometimes be good. Masochists, he says, desire suffering as an end in itself." Both true. But I never, not in a million years, used the latter true statement to rebut the former true statement, and this author does not quote me as saying any such thing.

I now claim that

1. murder is a violation of rights

And

2. some people commit "suicide by cop." That is, they are afraid to commit suicide themselves; instead, the pull a gun on a policeman, and welcome being killed by him.

Again, we have two true statements. Would I argue that the second refutes the first? Of course not. But that is in effect what Heumer is accusing me of.

In the view of this author: "My claim is that torturing animals on factory farms for the sake of trivial benefits for yourself, in the way that we are doing in actual reality, is wrong. Block has not attempted to identify any reason why that might be acceptable (emphasis added)."

Again, Heumer is confused about what libertarianism is all about. Hint, it has nothing to do with being "wrong." There are many things that are "wrong" that have nothing to do with this philosophy. It is "wrong" to get drunk. It is "wrong" to be obese. It is "wrong" to torture animals, as this author demonstrates eloquently. But libertarianism has no truck with "wrongness." It deals with rights violations, and only rights violations, all of which are also "wrong" but there are many things such as mentioned above that are "wrong" but not rights violations, and thus are irrelevant to libertarianism. This undermines his supposed adherence to this perspective.

\section{2. “Rights Require Homesteading”}

In the section, Heumer rejects the notion that rights go by species, not by races or hair color or any other such criterion. That is why comatose human beings who cannot petition for their rights ${ }^{5}$ still have them.

This scholar is widely and well known for his brilliant work on intuitions [31]. We can do worse than to follow his splendid lead in this regard. ${ }^{6}$ We know that it would be an act of murder to kill a baby, or a sleeping person, or a mentally handicapped individual, none of whom can petition for their rights. Only if rights are accorded to all members of a species are we logically entitled to arrive at any such conclusion. However, we all have to start somewhere. Perhaps it will be of some solace to this author that when and if any member of any of the intelligent species - dolphins, chimpanzees - ever demands the right to be left alone, free from human intervention, and promises to respect our equal rights, we shall have to grant this not only to that individual, but to every other member of that species.

Heumer points to the disanalogy between homesteading rights to people, and to land. He maintains there should be a logical consistency between the two. He casts aspersions on my claim that petitions for rights pertains to the entire species, since it does not at all apply to homesteading for land. In my opinion, this is an astute objection on this part. I had never before appreciated this bifurcation, and thus am in his debt for pointing this out to me. 
However, it will not suffice to undermine my and Rothbard's [54], [55] claim that rights petitioning for people applies to the entire species and is not properly confined to the individual members of the species who are capable of so doing. Why not? This is because there are strong dis-analogies between the two cases. Therefore, we cannot infer the one from the other.

Petitioning for personal rights applies to the entire species. In initial land ownership, only the actual homesteader obtains ownership, certainly not all or even any other members of his species. Where is the disanalogy between the two cases? For one thing, it is only because we first own ourselves that we are entitled to homestead the land in the first place. The "causal direction" if I may employ such a phrase, goes from the former to the latter, not the other way around. If a slave homesteads terrain, he does so in behalf of his master, not himself. For another thing, no one, not even non-libertarians, disputes the claim that land or other natural resources, once owned, may be sold, bartered, lent, given away, to other people. What about individual self-owners and thus rights-bearing entities? May they be sold, bartered, lent, given away, to other people? This is a highly contentious issue amongst libertarians. Some favor the legalization of voluntary slavery, people selling themselves to other people. ${ }^{7}$ Other libertarians vociferously oppose this. ${ }^{8}$ Again, there is no such division as to land. If that is not a disanalogy, and an important one, then nothing is.

\subsection{Reductio of the Risk Argument}

In this section, Heumer concocts all sorts of probabilities about suffering. For example: "If, for example, there is even a $1 \%$ chance that animal suffering is as important as human suffering, then the expected value of a year's worth of factory farming is equal to that of a program that tortures 740 million people." He demonstrates his dexterity with probability calculations, and I applaud him for his talents in that direction.

However, his major premise is false, and all that follows from it, however correct the deductions, must fall by the wayside also. That is, he once again misconstrues libertarianism. This is a deontological undertaking, not a matter of utilitarianism or pragmatism. The proper goal of this philosophy is to wrestle with questions of rights, responsibilities, justice, etc. For a utilitarian like Heumer, this sentence is not merely false, it is meaningless": "Justice though the heavens fall."

Having said that, and, with due allowances for interpersonal comparisons of utility and demonstrated preference [53], I am also happy to make the claim that not only is libertarian righteous, it also brings about the greatest amount of human happiness possible. For the only acts allowed in this viewpoint are voluntary ones, and every human action, without exception, improves the lot of the economic actor, at least ex ante. No other system can make that claim. For example, I buy a shirt for $\$ 10$. When I did, I valued this bit of clothing more than what I paid for it; the difference being the profit I earned from this purchase. The seller valued it at a lower rate than that, and thus also improved his economic welfare. ${ }^{10}$

\section{4. “Farming Is Good for Animals"}

I argue that if no one ate meat, most barnyard animals would simply disappear. Posit that that is true. Then, paradoxically, they would be worse off under total veganism, since it is better to exist than to disappear entirely.

Heumer offers a clever objection. He posits that there would be a group of human beings who were bred to be enslaved and kept in that status. Do I really favor such a situation, he challenges me? He then offers me the following syllogism and asks me to choose wherein I disagree:

1. The argument in defense of the meat industry is analogous to the argument in defense of the slave industry (with people who are specifically bred to be slaves).

2. The argument in defense of the slave industry is unsound. 
3. Therefore, the analogous argument in defense of the meat industry is unsound.

$\mathrm{He}$ is an intellectually bully. ${ }^{11}$ I'll grasp the horns of the dilemma he poses. I select the second premise. It is unsound, since a better situation would be one where this slavery was supported. Let me say that again: slavery would be justified under these weird conditions. And I don't mean voluntary slavery. I am now talking about the coercive variety that has occurred all too often in human history. ${ }^{12}$ But there is a caveat. The alternative is death. Joke: the economist is asked, "How is your wife?" Came the answer: "Compared to what?" Yes, we must delve into the alternative to coercive slavery here. And what, pray tell, is the alternative? It is death. I claim that from the welfare point of view of Heumer's slaves, they would be better off alive, and enslaved, rather than dead. One "proof" of this is that we have never had mass suicide on the part of slaves. ${ }^{13}$ That is, based on their own deliberations, they prefer slavery to death.

So, Heumer's attempt to bully me into accepting slavery in his example fails. I do accept it. Horrid as it is, it is preferable to death. Where there is a will there is a way. Where there is life, there is hope. Life is a very precious commodity. Who knows, a slave rebellion might succeed. Perhaps the evil slave holders will repent their monstrous ways, and engage in manumission. If all the slaves are dead, this cannot occur.

Similarly with animals. I repeat what I said in Block [20]: if I were the guardian of animals, the last thing I would want would be for them to disappear. My only question of Huemer in this section is, why was this not already fully comprehensible?

Note that in this section we are straying from deontological libertarianism. We are not discussing rights, here. Rather, we are engaged in a utilitarian analysis. Would animals, human slaves, be better off from a pragmatic point of view, if they did not exist at all. I claim they would be worse

off; Heumer demurs. Presumably, if this author were a slave he would commit suicide, not try to escape, overcome his masters, etc.

\section{5. “Animals Kill Other Animals”}

Chickens kill other chickens. Lions kill zebras. Wolves kill deer. We have rights only to the degree that we respect other people's rights. When human being A murders human being B, A loses his rights, in proportion to the rights of $\mathrm{B}$ he has disrespected. If we apply this to animals, that is, if animals have rights, then so do victimized chickens, zebras, deer, other victims of animal rights violations.

Yet no one, not even Heumer, favors bring up murder charges against these vicious chickens, lions and wolves. Rights come with responsibilities. If you have a right not to have violence initiated against you, you have an obligation not to do that to other people. If these predatory animals really had rights not to be killed by humans, they would not pick on other chickens, zebras and deer. But they do engage in these acts. Ergo, they do not have rights.

\section{6. “Rights Imply Responsibilities"}

Heumer denies this. He claims I have no justification for this "popular catch phrase." But this is no mere popular catch phrase. Rather, it stems from the fact that murders, thieves, rapists, lose their rights in proportion to those they violate. Let us turn matters inside out. What would it mean to deny that "Rights Imply Responsibilities?" It would imply that anyone could get away with anything at all. Want to murder, rape, enslave someone? Go ahead. Do it. You will not suffer any loss of your own previously held rights whatsoever. This doesn't sound very Kosher to me.

But Heumer has other arrows in his quiver on this matter. He again resorts to "babies, severely mentally retarded people, and severely mentally ill people." He claims that they "lack responsibilities, (therefore) they must have no rights; hence, we may torture and kill them at will," at least according to my analysis. No, no, no, such persons do indeed have responsibilities: they must refrain from killing, 
maiming and other criminal activities. It is difficult to see how babies can violate rights. ${ }^{14}$ How about sleeping people? Suppose there were a person who sleep-walked, and then killed in his nightly excursions. Would we hold him responsible for such an act? We certainly would, at the very least after the first such foray. If he didn't tie himself down in his bed after that, so that he could no longer sleepwalk, he would certainly be found guilty of murder. In his first such episode he would still be guilty of a crime, but, lacking mens rea, could not be accused of first-degree murder. But not after that! Mentally ill people can indeed commit mayhem. But when and if they did, they would be treated roughly akin to others who lacked mens rea.

\section{7. “Utilitarianism Supports Rape”}

Utilitarianism certainly can support rape, if and only if the rapist derives more pleasure from this despicable act than the victim suffers.

Heumer claims that this charge of mine against his views is "off-target" since it does not "address anything that I have ever said or thought." I certainly am not privy to his thoughts. I have had numerous meals and discussions with him, but what he said on these occasions is a tiny small percentage of his verbal utterances. However, I have read his book [32] and he continually inveighs against suffering. Indeed, even in his refutation of my claim as being "off-target" he once again emphasizes the importance he places upon reducing suffering; e.g., he offers a utilitarian calculus: "I simply argued that we should not inflict severe pain and suffering on other creatures for the sake of minor benefits to ourselves. This does not entail that no one has rights, nor did I in any way suggest that." Of course this does not imply that no one has any rights. But it certainly does "suggest" that Huemer places great importance on maximizing utility via the alleviation of suffering. Utilitarianism may be inferred in practically every sentence of this book. ${ }^{15}$ He never ever "simply" argues for the alleviation of pain and suffering. "Severe pain and suffering" vis a vis "minor benefits" sounds like utilitarianism to my ears; well, eyes. A fair reading of this publication of his will demonstrate the overarching emphasis he places on the alleviation of the former, and denigration of the latter. Well, let those who live by utilitarianism (intellectually) suffer from it as well. If the rapist derives more pleasure from his evil act than his victim loses utility, then Heumer is logically required to support this nefarious behavior of his. After all, net utility will increase as a result of it.

\section{8. “Experts Can Be Wrong”}

States Heumer: "In the Dialogues, I mentioned that most experts who review the ethical arguments concerning vegetarianism agree that they are compelling." In my review of this book, I gave a loud Bronx cheer to this notion, deprecating the expertise of some self-styled experts. As an illustration I chose humanities professors who wax eloquent about the shortcomings of laissez faire capitalism. Our author rejects this criticism on the ground that they are not really experts in economics.

Continues Heumer:

Now, unlike Block's example of humanities professors talking about economics, ethics professors who work on animal ethics actually are experts on that subject. They tend to be highly intelligent; to be well-informed about the relevant ideas, distinctions, and arguments in the field; and to have spent a long time thinking about the subject.

But the same identical thing can be said about "humanities professors talking about economics." They are also well versed in the dismal science, are well informed, spend much of their time denigrating economic freedom, despite the fact that their PhD's are in different subjects. However, Gary Becker's $\mathrm{Ph} . \mathrm{D}$. is in economics; yet, many of his major contributions are in sociology. Gordon Tullock's 
advanced degree was in law; yet many of his major contributions are in political science. Elinor Ostrom's Ph.D. was in political science; yet she won a Nobel Prize in economics; this is also true of Daniel Kahneman, a psychologist. David Friedman's Ph.D. is in physics, yet his major contributions are in law and economics. Heumer's understanding of credentialism varies widely from my own.

Moreover, there is the matter of social justice warriors, the cancel culture and wokesterism on

college campuses. The physical sciences and mathematics are the least infected by this virus, ${ }^{16}$ the social sciences especially economics occupy an intermediate position in this matter and the humanities are the worst violators of what universities are supposed to stand for: open inquiry, academic freedom, etc. Of all the humanities, philosophy is one of the very worst disciplines in this regard. ${ }^{17}$ So it comes with particular ill grace for Heumer to claim that those who specialize in this philosophical subdiscipline are "experts." Experts agree to dialogue, debate, as Heumer to his credit most certainly does. But the same cannot be said, unfortunately, for all too many of his colleagues.

\subsection{Shutting Down Modern Society}

Heumer accuses me of attributing to him the idea that his views require that "All activities that ever cause any harm at all are impermissible." But he is entirely mistaken in attributing to me this absurd claim against him. ${ }^{18}$

He maintains that he only "argued that factory farming is wrong because of the enormous amount of pain and suffering it causes, for the sake of trivial benefits for ourselves. ${ }^{19}$ This does not imply, nor did suggest, that everything that "causes any suffering or death at all is wrong." In other words, like the utilitarian that he is, he is offering a balancing scheme: if greater utility can be derived from something, and less harm, then it should be done; if not, then not.

What did I do, instead? I merely confined myself to helping with the utilitarian calculus. For example, deep coal mining is more dangerous than strip mining, given the same amount of product garnered. Therefore eschew the former, and support the latter. That is nowhere near akin to shutting everything down, the view he accuses me of attributing to him. Another instance: Flooding from dams not only kills human beings, but, also, Heumer's beloved animals. Unless it can be demonstrated that more pain will ensue for lack of these dangerous sources of energy, it would also behoove us to shun fuel derived thereby. Notice that I am getting with the utilitarian program: calculating pain and gain.

\section{Opposing Suffering}

Heumer notes that he and I are not so far apart in our tastes. He accepts my three-word summary of his book, "stop the suffering," and my enthusiastic agreement with it, and then wonders why I don't carry through and oppose factory farming? The reason is, I say this not in my capacity as a libertarian, but only insofar my tastes are concerned. As a personal matter, I like and admire Heumer, in large part because of his concern for the downtrodden species he so mightily and valiantly defends. But, as a libertarian, I note that since animals have no rights, factory farmers who engage in these practices are not criminals, and therefore it would be unjust to shut down their operations by law. Boycotts are of course another thing. They are entirely compatible with libertarian law. Why, then, do I continue to eat meat? One reason is that based on my own internal utilitarian calculus, the benefits outweigh the costs. Another is that it would be worse for the barnyard animals if we were all vegans, since they would then disappear, and I cannot believe that would be to their benefit. I absolutely abhor sadists who gain pleasure from torturing animals, but if experiments on them that cause them to greatly suffer get us closer to curing diseases that attack mankind, I am all in favor of them. People before animals is my motto.

Heumer ends his essay on a note of wonder about me. He states: "In case this hasn't been made sufficiently clear, the central thesis of my book was that it is morally wrong for us, right now, to buy 
products from factory farms, as almost everyone is doing. Almost none of Block's critique bears on that; almost none of it could be seen as even attempting to explain why it would be acceptable to buy factory farm products."

This author misunderstands my stance. I am first and foremost in these matters a libertarian. My main goal was to see what kind of overlap there is between his views and those of that philosophy. My conclusion: not too much. His concern is that it is "morally wrong" to patronize factory farms. Libertarianism is only concerned with a small slice of overall morality, that dealing with private property rights and the initiation of violence against human beings, not animals.

I have been very thorough in my response to Heumer [33]. I replied to each and every point he made in this essay of his. He has not done me the honor of being responsive to me [20]. I announced, there, that my main focus would be on determining to whether or not, and if so the extent to which, his views could be characterized as libertarian. I am still in the dark as to how he would deal with that challenge. He never responded to my point that libertarianism is concerned with but a small subset of overall ethics. Did he respond to my reductio that a large corporation earned a small profit, garnering them a small gain, while as a result a small mom and pop operation had to close their doors, suffering grievously? No, he did not. I mentioned that "petitioning so all-important" because it is predicated on homesteading. Another avoidance by Heumer. Ditto for burning a cat for pleasure vis a vis torturing an animal so as to cure cancer; his utilitarian, not libertarian, analysis of the nuclear bomb in the basement; my devastating response to his challenge about killing one person or 100 pigs; his analysis of the Killian case (stand in for factory farms) and eliminating trading relationships with the likes of Cuba, Venezuela, North Korea, China; the supposed immorality of Prostitution, pornography, addictive drugs, gambling, homosexuality, masturbation, fornication; why only "consider" stopping lions from killing zebras?; the subjectivity of "enormous" and "minor"; my riposte about chocolate covered ants; my query about "free range farm animals, humane certified meat"; the fact that his punishment theory will encourage criminality.

Nevertheless, I learned a lot from his response to my book review, and I am very grateful to him for it. If ever he pens a response to this present missive, maybe he will condescend to respond to these other issues.

\section{References}

1. Andersson, A. An alleged contradiction in Nozick's entitlement theory. Journal of Libertarian Studies, 21(3), Fall, 2007, 43-63.

2. Barnett, R. E. Contract Remedies and Inalienable Rights. Social Philosophy \& Policy, 4(1), Autumn, 1986, pp. 179-202.

3. Barnett, R. E. The Structure of Liberty: Justice and the Rule of Law, Oxford: Clarendon Press, 1988.

4. Barnett, R. E. Libertarians and the War. Wall Street Journal. July 17, 2007.

5. Barnett, W. II, Block, W. E. Economic categorization. Laissez-Faire, Issue 28-29, March-September 2008, pp. 4-12.

6. Block, W. E. Voluntary Slavery. The Libertarian Connection, 1(3), April 13, 1969, pp. 9-11.

7. Block, W. E. Book review of Nancy C. Baker, Baby Selling: the Scandal of Black Market Adoptions, New York: The Vanguard Press, 1978, Libertarian Review, 7(12), January, 1979, pp. 4445.

8. Block, W. E. Market Inalienability Once Again: Reply to Radin. Thomas Jefferson Law Journal, 22(1), Fall: 1999, pp. 37-88.

9. Block, W. E. Alienability, Inalienability, Paternalism and the Law: Reply to Kronman. American Journal of Criminal Law, 28(3), Summer, 2001, pp. 351-371.

10. Block, W. E. A Libertarian Theory of Secession and Slavery. Lew Rockwell, June 10, 2002. 
11. Block, W. E. Toward a Libertarian Theory of Inalienability: A Critique of Rothbard, Barnett, Gordon, Smith, Kinsella and Epstein. Journal of Libertarian Studies, 17(2), Spring, 2003, pp. 39-85.

12. Block, W. E. Are Alienability and the Apriori of Argument Logically Incompatible? Dialogue, 1(1), 2004.

13. Block, W. E. Ayn Rand and Austrian Economics: Two Peas in a Pod. The Journal of Ayn Rand Studies, 6(2), Spring, 2005, pp. 259-269.

14. Block, W. E. Epstein on alienation: a rejoinder. International Journal of Social Economics, 33(3-4), 2006, pp. 241-260.

15. Block, W. E. Secession. Dialogue, 4, 2007A, pp. 1-14; http://www.unisvishtov.bg/dialog/2007/4.07.WB.pdf.

16. Block, W. E. Alienability: Reply to Kuflik. Humanomics, 23(3), 2007B, pp. 117-136.

17. Block, W. E. Yes, Sell Rivers! And Make Legal Some Slave Contracts. The Tyee. July 25, 2009.

18. Block, W. E. Privatizing Rivers and Voluntary Slave Contracts. Lew Rockwell. July 27, 2009.

19. Block, W. E. Walter Block Issues Statement About His Lawsuit Against The New York Times.

Target Liberty, August 14, 2015;

http://www.targetliberty.com/2015/08/walter-block-issues-statement-about-

his.html?utm_source=feedburner\&utm_medium=email\&utm_campaign=Feed $\% 3 \mathrm{~A}+$ TargetLiberty+\% 2

8Target+Liberty\%29 nytimes.

20. Block, W. E. On Huemer on Ethical Veganism. Studia Humana, 9(2), 2020, pp. 53-68.

21. Boldrin, M., and D. K. Levine. Against Intellectual Monopoly. Cambridge: Cambridge University Press, 2008

22. Calabresi, G., and D. Melamed. Property Rules, Liability Rules, and Inalienability: One View of the Cathedral. Harvard Law Review, 85(6), April, 1972, pp. 1089-1128.

23. Cesario, A. J. Reconciling the Irreconcilable: A Property Rights Approach to Resolving the Animal Rights Debate. Studia Humana, 2021, pp. 1-33.

24. Epstein, R. Why Restrain Alienation. Columbia Law Review, 85(970), 1985.

25. Evers, W. Toward a Reformulation of the Law of Contracts. Journal of Libertarian Studies, 1, Winter, 1977, pp. 3-13.

26. Frederick, D. Voluntary Slavery. Las Torres de Lucca, 4, 2014, pp. 115-37.

27. Gordon, D. Private Property's Philosopher. The Mises Review, 5(1), Spring, 1999, pp. 1-7.

28. Gordon, D. From Intuitions to Anarchism? Journal des Economistes Et des Etudes Humaines, 26(1), 2020.

29. Huemer, M. The Problem of Political Authority: An Examination of the Right to Coerce. Palgrave Macmillan, 2012.

30. Huemer, M. Defending Libertarianism: The Common Sense Approach, 2013; https://www.youtube.com/watch?v=vmCn2vP-DEo.

31. Huemer, M. An Ethical Intuitionist Case for Libertarianism. Libertarianism.org, January 3, 2017; https://www.libertarianism.org/publications/essays/ethical-intuitionist-case-libertarianism.

32. Huemer, M. Dialogues on Ethical Vegetarianism, New York: Routledge, 2019.

33. Heumer, M. Reply to Walter Block on Ethical Vegetarianism. Studia Humana, 10(1), 2021, pp. 4150.

34. Kershnar, S. A Liberal Argument for Slavery. Journal of Social Philosophy, 34(4), 2003, pp. 51036.

35. Kinsella, N. S. Reply to George Smith: A Victim's Right to Punish. Journal of Libertarian Studies, 14(1), Winter, 1998-1999, pp. 79-93.

36. Kinsella, N. S. Inalienability and Punishment: A Reply to George Smith. Journal of Libertarian Studies, Winter, 1998-1999.

37. Kinsella, N. S. A Libertarian Theory of Contract: Title Transfer, Binding Promises, and Inalienability. Journal of Libertarian Studies, 17(2), Spring, 2003, 11-37. 
38. Kronman, A. Paternalism and the Law of Contracts. Yale Law Journal, 92(5), 1983.

39. Kuflik, A. The Inalienability of Autonomy. Philosophy and Public Affairs, 13(4), Fall, 1984, pp. 271-298.

40. Kuflik, A. The Utilitarian Logic of Inalienable Rights. Ethics, 97, October 1986, pp. 75-87.

41. Lester, J. A. Escape from Leviathan. St. Martin's Press, 2000.

42. Long, R. Slavery Contracts and Inalienable Rights: A Formulation. Formulations, Winter, 19941995.

43. McConnell, T. The Nature and Basis of Inalienable Rights. Law and Philosophy, 3(1), 1984, pp. 25-59.

44. McConnell, T. The Inalienable Right of Conscience: A Madisonian Argument. Social Theory \& Practice, 22(3), Fall, 1996, pp. 397-416.

45. Mosquito, B. The Sanctity of Contract. April 19, 2014.

46. Narveson, J. Animal Rights. Canadian Journal of Philosophy, 7(1), 1977, pp. 161-178.

47. Nozick, R. Anarchy, State and Utopia, New York: Basic Books, 1974.

48. Radin, M. J. Time, Possession and Alienation. 64 Washington University Law Quarterly 739, 64(3), 1986.

49. Radin, M. J. Market-Inalienability. Harvard Law Review, 100(8), June, 1987, pp. 1849-1937.

50. Regan, T. An Examination and defense of one Argument concerning Animal rights. Inquiry: An Interdisciplinary Journal of Philosophy, 22(1-4), 1979, pp. 189-219.

51. Reisman, G. Capitalism. Ottawa, Il.: Jameson Books, 1996.

52. Rothbard, M. N. The Ethics of Liberty, Humanities Press, Atlantic Highlands, N.J., 1998 [1982], pp. 40-41, 135-136.

53. Rothbard. M. N. Toward a Reconstruction of Utility and Welfare Economics. reprinted in The Logic of Action Vol. I. Lyme, NH: Edward Elgar. 1997 [1956], pp. 211-254.

54. Rothbard, M. N. For a New Liberty, Macmillan, New York, 1973.

55. Rothbard, M. N. Ethics of Liberty, New York City, NY: New York University Press, 1998 [1982].

56. Singer, P. Animal Liberation. New York, NY: Avon Books, 1975.

57. Smith, G. A Killer's Right to Life. Liberty, 10(2), November, 1996, pp. 46-54.

58. Smith, G. Inalienable Rights? Liberty, 10(6), July, 1997, p. 51.

59. Steiner, H. An Essay on Rights, Oxford: Blackwell Publishers, 1994.

60. Steiner, H. Directed Duties and Inalienable Rights. Ethics, 123, January, 2013, pp. 230-244.

61. Thomson, J. J. The Realm of Rights, Cambridge, MA, Harvard University Press, 1990.

62. Unknown Author. No date. But What About Voluntary Slaves?;

https://voluntaryistreader.wordpress.com/2012/12/29/but-what-about-voluntary-slaves/.

63. Waldau, P. Animal rights: what everyone needs to know. Oxford University Press, 2010.

\section{Notes}

1. I wish to thank an anonymous referee of this journal for help in improving an earlier version of this paper and A. J. Cesario for a splendid copy-editing job. All remaining infelicities and substantive errors are of course my sole responsibility.

2. For a background on the debate over animal rights, see [23], [46], [50], [52], [56], [63].

3. Unless otherwise mentioned, all references to Heumer will be to this one [33] article of his.

4. This claim is buttressed by Heumer, [29], [30], [31]. Further, the Bleeding Heart Libertarian blog is one of the most important platforms in the libertarian movement and Michael Heumer is one of the most prominent members of this organization:

https://www.google.com/search?q=Bleeding+Heart+Libertarians+Michael+Heumer\&rlz=1C1CHBF_enUS724US724\&oq= Bleeding+Heart+Libertarians+Michael+Heumer\&aqs=chrome..69i57.444j0j15\&sourceid=chrome\&ie $=U T F-8$

5. Strictly speaking, they must not only petition for their rights, demand them, complain of their absence, but must also promise to respect the rights of human beings, and act accordingly. No animal, no matter how intelligent, comes anywhere near being capable of acting in any such manner. 
6. But see Gordon [28] for a critique

7. [1], [6], [7], [8], [9], [10], [11], [12], [13], [14], [15], [16], [17], [18], [21], [26], [34], [41], [45], [47, pp. 58, 283, 331], [59, pp. 232-233], [60, pp. 230-244], [61, pp. 283-284].

8. [2], [3], [22], [24], [25], [27], [35], [36], [37], [38], [39], [40], [42], [43], [44], [48], [49], [51, pp. 455f., 634-636], [52, pp. 40-41, 135-136], [57], [58], [62].

9. To return the favor, I would say the same about this phrase: "If ... there is even a $1 \%$ chance that animal suffering is as important as human suffering..."

10. But what about the case where someone else wanted that shirt and I outbid him for that. Does not his negative welfare, his pain and suffering, have to enter the calculation? No. As Rothbard [53] demonstrates, this person has no way of demonstrating his welfare loss. The only counterexample to the claim that laissez faire capitalism necessarily maximizes human(!) welfare are concocted scenarios such as the following. The all-powerful Martians beam down a message to us to the effect that unless we murder an innocent person, they'll blow up the entire earth and all of us will die. A hero steps up and murders that individual. Whereupon libertarianism swings into action once again, and we are about to execute this heroic murderer. The Martians send down another message: if we do that, that is, if we follow libertarian principles in this or any other way, they will pulverize our planet. Then and only then in these types of made up examples, can a wedge be created between utilitarianism and libertarianism.

11. I mean this as a compliment!

12. Please, no one tell the New York Times about this! See on this Block [19].

13. Perhaps Masada is a counter example. Fools. They should have stayed alive and killed at least a few more of their enemies, from their own perspective.

14. Ok, ok, they cry and keep people awake, but let's be serious here.

15. I exaggerate of course, but only somewhat.

16. Although even they are now coming under fire as racists for insisting that $2+2=4$.

https://www.google.com/search?q=mathematicians+are+racists+for+insisting+that+2\%2B2\%3D4.\&rlz=1C1CHBF_enUS7 24US724\&oq=mathematicians+are+racists+for+insisting+that+2\%2B2\%3D4.\&aqs=chrome..69i57.10932j0j15\&sourceid=c hrome \&ie=UTF-8

17. The Peter Boghossian case is only the latest episode in this sorry story.

https://www.google.com/search?q=is+philosophy+the+most+woke+discipline\%3F\&rlz=1C1CHBF_enUS724US724\&sxsrf $=$ AOaemvLgGe7SI9m_-

IYSfadCanJz5XngWQ\%3A1631407941106\&ei=RU89YZT6Be3v9AOWn6aICQ\&oq=is+philosophy+the+most+woke+dis cipline\%3F\&gs_lcp=Cgdnd3Mtd216EAM6BggAEAcQHjoFCAAQgAQ6BAgAEB46BAgAEA06BggAEA0QHjoICAAQB xAFEB46BggAEAUQHjoICAAQCBANEB46BAghEApKBAhBGABQ10dYu5ABYNKZAWgAcAJ4AIABaYgBhwSAQQyNi4xmAEAoAEBwAEB\&sclient=gws-

wiz\&ved=0ahUKEwjUsMCWnPjyAhXtN30KHZaPCZEQ4dUDCA4\&uact=5. Unfortunately, I was unable to delve further into the sub-disciplines in philosophy, but I suspect that those who engage in symbolic logic are the least given to this type of academic arrogance, and those who focus on animal rights among the most.

18. I do wish he would at least upon occasion do me the honor of citing my actual words, as I do of his. If he did so, this might preclude him from ascribing to me objections to his thesis that I never made.

19. If this is not an instance of utilitarianism, I don't know what is. 